\title{
Por uma santidade integral: a problemática do Dualismo no Pentecostalismo brasileiro e as contribuições de Karl Barth
}

\author{
Orientador: Luís Corrêa Lima
}

Doutorando: Jansen Racco Botelho de Melo

Área de Concentração: Teologia Sistemático-Pastoral

Linha de Pesquisa: Religião e Modernidade

Projeto de Pesquisa: História da Igreja e Modernidade: Permanências e Mudanças

O Movimento Pentecostal é o ramo mais representativo do protestantismo brasileiro atual. É um Movimento que, historicamente, tem se comunicado com as classes menos favorecidas da sociedade brasileira e tem sido um Movimento Pneumatológico e Eclesial importante no cenário religioso hodierno. No Pentecostalismo, assim como no cristianismo ocidental em geral, a presença do dualismo tem sido um fator de distanciamento da proposta de Jesus e de distorções acerca da espiritualidade. O pensamento do teólogo suíço Karl Barth é um sistema de reflexão que trabalha com pontos muito parecidos com os do Pentecostalismo brasileiro, como a Pneumatologia, a Eclesiologia, a Espiritualidade, etc, porém, no pensamento barthiano percebemos os mesmos elementos sendo compreendidos de modo integral, num caminho de superação das distorções e aproximação da santidade proposta por Jesus de Nazaré.

Palavras-chave: Pentecostalismo. Dualismo. Integralidade. 